\title{
Occurrence and behaviour of monazite-(Ce) and xenotime-(Y) in detrital and saprolitic environments related to the Serra Dourada granite, Goiás/Tocantins State, Brazil: potential for REE deposits
}

\author{
Igor V. Santana, Frances Wall, Nilson F. Botelho
}

July 28,2015

\begin{abstract}
The mode of occurrence, mobility and fractionation of REE have been investigated in the geochemical context of the Serra Dourada Granite, an A-type granitic body located in northern Goiás State, Brazil. Several analyses were performed to best characterize each mode of occurrence of REE, from fresh rock to its products of alteration such as the saprolite, placers and clayish horizon. In the fresh rock it was found that the REE budget is related to monazite- $(\mathrm{Ce})$, xenotime-(Y), bastnäsite and allanite. Resistant monazite- $(\mathrm{Ce})$ and xenotime- $(\mathrm{Y})$ withstand fluvial transportation and are concentrated in placers whithin the massif, whereas bastnäsite and allanite do not. The alluvial sediments contain up to $0.87 \mathrm{wt} \%$ monazite-(Ce) and 0.46 wt $\%$ xenotime- $(\mathrm{Y})$. Considering only the heavy minerals, monazite-(Ce), zircon and ilmenite represent $60-80 \%$ of the total variability, being monazite- $(\mathrm{Ce})$ and xenotime- $(\mathrm{Y})$ the most important REE carriers. The same minerals are also present, although in lower amounts, in the saprolite. Both qualitative and quantitative electron probe microanalysis were carried out in detrital monazite(Ce) and xenotime-(Y) to assess their main features and composition. Monazite-(Ce) REE contents are $60 \mathrm{wt} \%$ in average, whilst REE contents in detrital xenotime-(Y) are $55 \mathrm{wt} \%$ in average. Low totals are ascribed to the alteration of the minerals caused by the presence of both organic and inorganic ligands present in the system. The results support the idea that REE are mobile under supergene conditions and during granite weathering, tending to be higher and more fractionated towards the products of alteration (saprolite, alluvial sediments and clayish horizon). $\mathrm{REE}_{2} \mathrm{O}_{3}$ contents in the fresh granite, saprolite, alluvial sediments and clayish horizon are $0.07,0.21,1.2$ and $0.11 \mathrm{wt} \%$ respectively, the clayish horizon being HREE-selective. Placer deposits and the clayish horizon tend to occur in low-slope areas within the Massif, where deposition and accumulation is more favorable. The saprolite occurs preferably in high-slope areas formed in situ at the expense of the granite. The placer deposits could be exploited, but their occurrence is more restricted and local. The saprolite has the advantage of covering extensive areas widely distributed over the granite. Currently a private company, the Serra Verde Mining, posses the mining claims in the area to exploit the REE associated with the saprolite, under the model of ion-adsorption type deposits.
\end{abstract}

\section{Introduction}

In recent years an abrupt disruption in supply of rare earth elements (REE) along with increasing demand has driven the attention of governments worldwide to the security of supply issues; REE have become "critical" materials. The international rush to find new REE resources is a consequence of the increasing usefulness of REE in high-technology devices, the development of green energy sources and use in several other applications including the defence industry. Dependant and non-producing countries have started prospecting campaigns in order to guarantee supply for their industries. The heavy REE (HREE; Gd-Lu + Y) are especially critical and scarcer than the light REE (LREE; La-Eu) so that several current prospect campaigns are focusing on these. The HREE are raw materials for a diverse range of high-technology devices, from aerospace communications to nuclear magnetic resonance scanning in hospitals.

Monazite (Ce,La) $\mathrm{PO}_{4}$ and xenotime $\mathrm{YPO}_{4}$ are two major REE ores. They are relatively common as accessory phases in peraluminous granites, syenites, pegmatitic granites, quartz veins and carbonatites, in 
addition to charnockites, migmatites and paragneisses (Rapp and Watson, 1986). Economic occurrences of these minerals are typically found in placer deposits downstream or associated with coastal sediments, owing to their resistance to weathering and high density. This study reports the occurrence and characterization of these minerals sampled from placers, in the context of a wider geochemical scenario involving REE fractionation and enrichment from fresh rock to its alteration products. The objective is to better understand REE behaviour, from weathering of its source rock to accumulation in the sedimentary record, and ultimately evaluate the geologic potential of the prospect as a REE source. The target is the Serra Dourada granite, an A-type massif located in northern Goiás State, first described by Marini and Botelho (1986), who drew attention to its potential as a tin source and its high REE content.

A number of studies regarding granite weathering, REE behaviour, detrital monazite- $(\mathrm{Ce})$ and xenotime(Y) can be cited as references in the subject. These include Aubert et al. (2001); Boulangé and Colin (1994); Condie et al. (1995); Coppin et al. (2002); Nesbitt (1979); Duddy (1980); Ruan and Guocai (1998); Wu et al. (1996); Chengyu et al. (1990); Murakami and Ishihara (2008); Bao and Zhao (2008); Sanematsu et al. (2009 2013); Mentani et al. (2010). These papers give support to the idea that the REE are mobile under supergene conditions, in opposition to what was previously believed. REE fractionation during weathering processes is an accepted geological fact but its exact behaviour is sometimes difficult to predict due to several variables. These include the nature of the host rock and original REE mineralogy, nature of hydrothermal and supergene fluids, climate conditions, terrain declivity, acidity of meteoric and groundwater, presence of organic acids, etc. Another common point is that climatic weathering and stability of the REE-bearing minerals acts as a major control on the lanthanide mobility during weathering processes.

The favourable economic scenario for the REE adds value to the present study because the deposits has potential to be exploited in the short term, in addition to the contribution to the better understanding of REE behaviour during weathering of granites. Currently, the Serra Verde Mining is carrying out prospecting and, evaluation surveys in the area targeting the REE-enriched saprolite of the granite. Another advantage of this type of deposit is that mining alluvial heavy minerals is relatively simpler than hard-rock mining. The minerals of interest could be readily separated in situ, and there is always the possibility of obtaining co-products that occur with monazite- $(\mathrm{Ce})$ and xenotime- $(\mathrm{Y})$, such as zircon, titanite, garnet, tourmaline, kyanite, staurolite, and cassiterite (Long et al. 2012).

\section{Geological framework}

The northern region of Goiás State has been the target of several studies owing to its complex geological setting, the understanding of which is essential to reconstruct the geological evolution of central Brazil. Moreover, occurrences of REE, $\mathrm{Sn}, \mathrm{Au}, \mathrm{Cu}, \mathrm{Zn}, \mathrm{Ni}$, asbestos, decoration stones and gem-quality tourmalines have been reported in the region since the 1970s.

\subsection{Serra Dourada granite}

The Serra Dourada Granite (SDG) is part of the so-called Goiás Tin Province, a term coined by Marini and Botelho (1986). The Province is made up by twenty granitic bodies and pegmatitic veins of Paleoproterozoic to Neoproterozoic ages, subdivided into four groups according to their localities. The Rio Tocantins and Rio Paranã subprovinces are the most studied, located in northern Goiás State. According to Marini and Botelho (1986), granites of these subprovinces exhibit petrographic, geochemical and tectonic signatures that allow them to be classified as A-type granites. They are also alkali-rich and have high F, Sn, Rb, Th, Nb, Ga and $\mathrm{REE}+\mathrm{Y}$ contents. The presence of evolved facies formed by late to post-magmatic alteration processes has been reported, the most common being microclinization, albitization and greisenization.

The SDG (Figure 1) is the largest body of the RTS, with dimensions of $55 \mathrm{~km}$ length and up to $13 \mathrm{~km}$ width. It is located in northern Goiás State, next to the Municipalities of Montividiu do Norte and Palmeirópolis. The main facies is a biotite granite constituted of quartz, perthitic orthoclase, oligoclase and biotite. Zircon, apatite, monazite-(Ce), fluorite, ilmenite, pyrite and chalcopyrite are the main accessory minerals (Macambira, 1983 Bilal et al. 1997). Important REE-bearing minerals include monazite-(Ce), xenotime-(Y), allanite, bastnäsite-group minerals, apatite and thorite. According to Macambira (1983) and Bilal et al. (1997) the main facies is sometimes cut by a porphyritic granite made up by plagioclase, quartz, biotite, allanite and late microcline phenocrysts. They also reported the occurrence of a mylotinized orthogneiss at the borders 
of the massif, as well as more evolved hydrothermal facies such as albitites and biotitites. Pimentel et al. (1991) carried out dating measurements using $\mathrm{U} / \mathrm{Pb}$ and $\mathrm{Pb} / \mathrm{Pb}$ systems, which yielded ages between 1.57 and $1.61 \mathrm{Ga}$. The SDG is surrounded by the mica schist of the Serra da Mesa Group.

Cassiterite in placers and hosted in albitites was exploited during the 1980s, specially in the Cruzeiro, Pela Ema and Buriti mines, located in the southern border of the granite. Other occurrences include tourmaline and beryl-hosted pegmatites, in addition to monazite- $(\mathrm{Ce})$ and xenotime- $(\mathrm{Y})$ in placers.

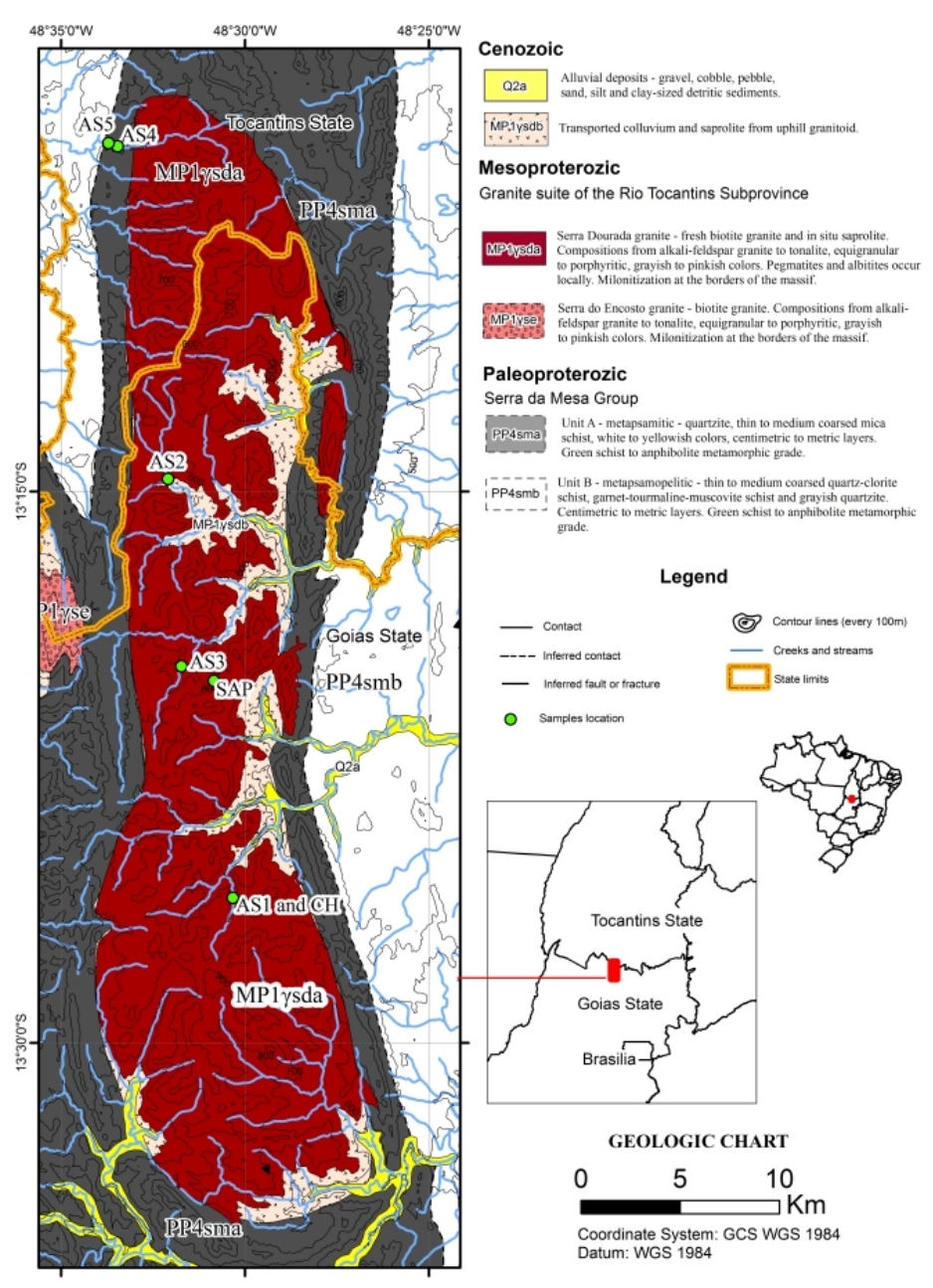

Figure 1: Local geological map and sampling locations in the Serra Dourada granite.

\section{Material and methods}

\subsection{Field sampling strategy}

To support the sampling strategy a base map was compiled based in previous geological reconnaissance in the study area, data from Petersen Jr et al. (2008) and one mapping project of the Brazilian Geological Survey - Mata Azul Chart. Topographic map and Landsat 8 images were also used to infer the main lithological contacts, general lineaments and structural features. 
Three unweathered samples of the biotite granite were taken from the top of hills and its immediate slopes to depict the fresh granite (samples FG1, FG2, FG3) and one sample of weathered granite was taken to depict the in situ saprolite (sample SAP). Altitudes below approximately $600 \mathrm{~m}$ mark the colluvionar domain in which transported saprolite from uphill granitoids occurs. It was not analysed in this study because it is chemically similar to the in situ saprolite. It it is important to map though because it can provide useful information on the location of paleoplacers. One clayish horizon (sample $\mathrm{CH}$ ) was taken from an exposed channel of the Retiro Creek, also occurring at altitudes below $600 \mathrm{~m}$ in average. One sample of alluvial sediments (sample AS1) was taken from the same creek, and samples AS2, AS3, AS4 and AS5 were taken from other creeks (refer to the map in Figure 1 for sampling locations). To pinpoint the best sampling points in the placers we used a gamaspectrometer, since the assemblage of heavy minerals include Th-U-bearing minerals such as monazite-(Ce), xenotime-(Y) and zircon. The amount of material was sampled considering the further analytic procedure. Approximately 200-300g of material was enough to facilitate all the analyses needed. Weathered material was dried at low temperature (about $40^{\circ} \mathrm{C}$ ) to avoid interference in hydrous minerals and stored in plastic bags. Fresh rock was sampled according to its granulation, i.e. the coarser the granulation the bigger the sample to be more representative.

\subsection{Analytical methods}

Whole-rock analyses for major and minor elements were carried out at ACME laboratories in Canada using ICP-AES and ICP-MS, following a lithium borate fusion and dilute acid digestion of $0.2 \mathrm{~g}$ sample pulp.

Two rounds of electron probe microanalyses (EPMA) were carried out in detrital monazite-(Ce) and xenotime-(Y), and will be refereed to EPMA 1 and EPMA 2. The EPMA 1 was carried out at University of Brasília with a JEOL JXA-8230. The analytical conditions were: $25 \mathrm{kV}$ acceleration voltage; 50nA electron current and beam diameter of $3 \mu \mathrm{m}$. Standards were as follows: synthetic glasses for the REE; a synthetic oxide of $\mathrm{Fe}$ and $\mathrm{Y}$ for $\mathrm{Y}$; natural oxides for the elements $\mathrm{U}$ and $\mathrm{Th}$; and galena for $\mathrm{Pb}$. The elements $\mathrm{Ca}$ and $\mathrm{Si}$ were standardized with wollastonite and $\mathrm{P}$ with apatite. $\mathrm{K} \alpha$-lines were used for $\mathrm{P}, \mathrm{Al}, \mathrm{Si}, \mathrm{Ca}$ and $\mathrm{Fe}$; $\mathrm{L} \alpha$-lines were used for $\mathrm{Y}, \mathrm{La}, \mathrm{Ce}, \mathrm{Er}$, and $\mathrm{Yb}$; and $\mathrm{L} \beta$-lines were used for $\mathrm{Pr}, \mathrm{Nd}, \mathrm{Sm}, \mathrm{Gd}, \mathrm{Tb}, \mathrm{Dy}$, and Ho. For $\mathrm{U}$, Th, and $\mathrm{Pb}, \mathrm{M} \beta, \mathrm{M} \alpha$ and $\mathrm{M} \beta$-lines, respectively.

EPMA 2 was carried out at Camborne School of Mines with a JEOL JXA-8200 Super probe. The acceleration voltage applied was $20 \mathrm{kV}$ with electron current of $20 \mathrm{nA}$ and spot size of $3 \mu \mathrm{m}$. The results were quantified with reference to pure oxides for the REE, Th and U; P and Ca were standardized with apatite, Si with jadeite. K $\alpha$-lines were used for P, Si and Ca; L $\alpha$-lines were used for La, Ce, Nd, Sm, Eu, Gd, Dy, $\mathrm{Er}, \mathrm{Tm}, \mathrm{Yb}$ and $\mathrm{Y}$; and $\mathrm{L} \beta$-lines were used for $\mathrm{Lu}, \mathrm{Ho}$ and $\mathrm{Pr} ; \mathrm{M} \alpha$ lines were used for $\mathrm{U}$ and Th.

The major mineralogy of the saprolite, clayish horizon and the concentrate of heavy minerals was determined on a Siemens D5000 X-Ray Diffractometer ( $\mathrm{Cu} \mathrm{K \alpha}$ radiation, $40 \mathrm{kV}$ and $30 \mathrm{~mA}$ ) at Camborne School of Mines. The samples were scanned at room temperature over angles of $2^{\circ}$ to $70^{\circ} 2 \theta$, on a $0.02^{\circ}$ step with a step time of 1s. Samples were rotated during measurement to minimise the effects of preferential mineral orientation. Peaks were interpreted using the JCPDS PDF-2 (2004) database and EVA software V.10.0.1.0. Detection limits are of the order of 3 to $5 \mathrm{wt} \%$ approximately, but this is mineral and sample dependant. Quartz always appears as a stronger peak than it actually is.

Raman spectroscopy was carried out at room temperature in a WITec alpha 300R at University of Exeter. The spectra were measured using excitation laser of $532 \mathrm{~nm}$. Each Raman spectrum is composed of 20x0.5 sec integrations, average laser power at sample of $40 \mathrm{~mW}$.

\section{Results}

\subsection{Unweathered biotite granite}

The parental rock is medium-to-coarse-grained equigranular biotite granite. The REE budget observed in the fresh granite is made up mainly by monazite- $(\mathrm{Ce})$, xenotime- $(\mathrm{Y})$, allanite and bastnäsite-group minerals. Monazite-(Ce) and xenotime-(Y) occur as colorless grains, anhedral to subhedral, frequently associated with biotite, zircon and thorite. In thin section, observed sizes range from 10 to $100 \mu \mathrm{m}$ but crystals with up to $1.5 \mathrm{~mm}$ were recovered from placers. Allanite is relatively common in the granite, occurring as euhedral to anhedral grains. Most specimens were found in advanced degree of alteration, brownish to reddish 
colors, several microfractures, sizes of $1 \mathrm{~mm}$ or less. Fresh allanite is larger, sizes up to $4 \mathrm{~mm}$, euhedral crystals, moderate relief and pale yellow to reddish brown colors. Fractures in altered allanite are replaced by bastnäsite-group minerals, forming veinlets within the grain or even some "clusters", when several veins intercept each other. Bastnäsite also occurs as acicular and fibrous aggregates. The minerals and their associations can be seen in Figure 2. Whole-rock analyses of the fresh granite can be seen in the Table A.1 - Appendix A: samples FG1, FG2 and FG3.
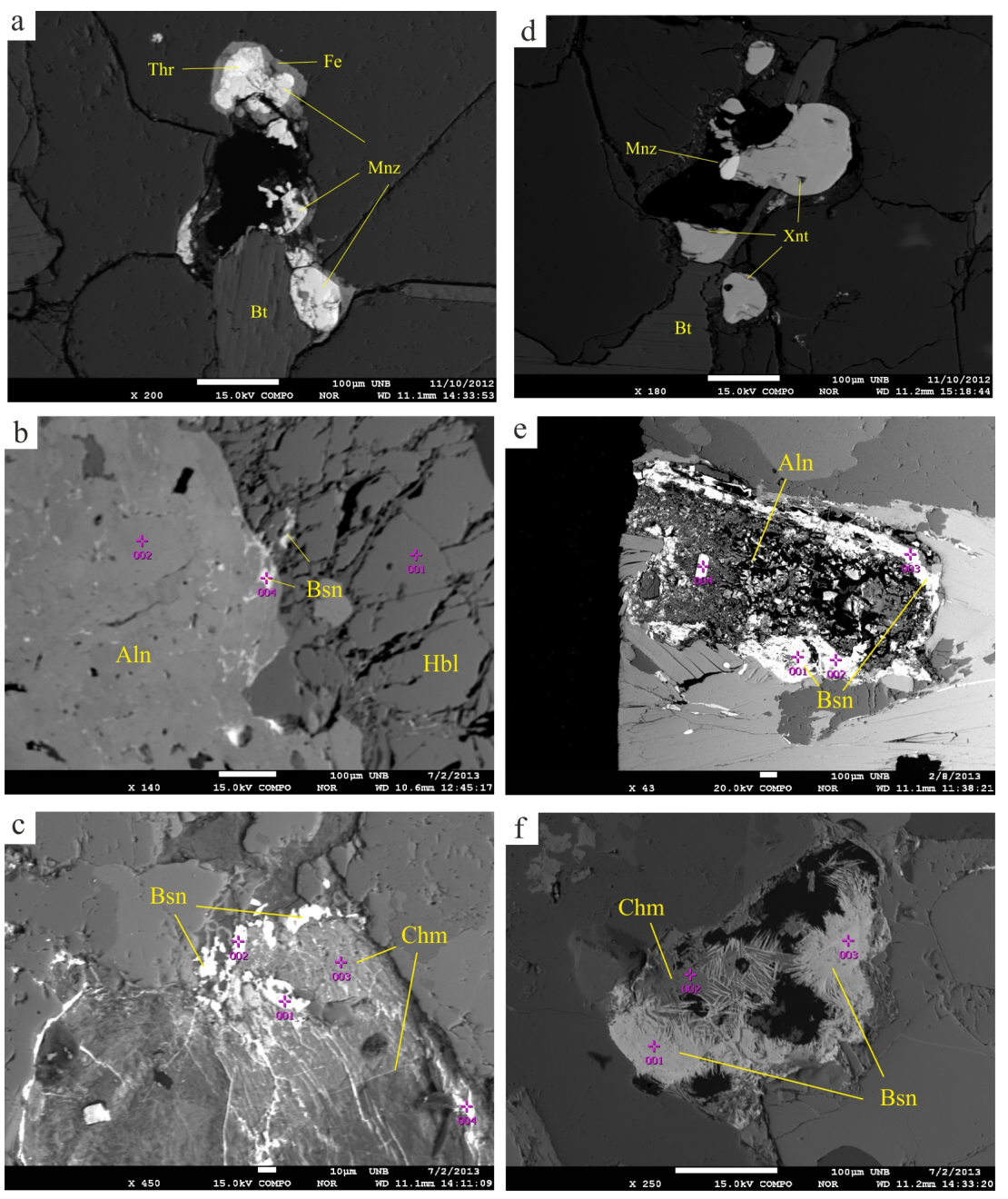

Figure 2: Back-scattered electron images of REE-bearing minerals in the fresh granite. (a) Monazite$(\mathrm{Ce})(\mathrm{Mnz})$ and thorite(Thr), both surrounded by Fe oxide rim(Fe) and associated with biotite. (b) Relatively fresh allanite (Aln) with minor bastnäsite (Bst) inclusions. (c) Altered allanite exhibiting veinlets and clusters of bastnäsite and chamosite $(\mathrm{Chm})$. (d) Rounded xenotime-(Y) and monazite-(Ce) next a biotite grain. (e) Deeply-altered allanite with bastnäsite rim. (f) Acicular crystals of bastnäsite and chamosite.

\subsection{Saprolite}

The saprolite crust occurs on the top of hills and their immediate slopes, developed in situ at the expense of the biotite granite, forming a typical profile of litholic neossol (Figure 3). The weathered profile is composed of three horizons A, B and C. Horizon A is composed of soil abundant in organic matter, average thickness of $5-10 \mathrm{~cm}$, dark brown colors. Horizon B is mostly composed of weathered granite; with the naked eye it is possible to distinguish that quartz, relicts of biotite and feldspars are still present, but the predominant phase is a mixture of white to grayish clays, members of the kaolinite group. Horizon B is approximately 
$3 \mathrm{~m}$ thick, in which the original texture of the granite is somewhat discernible, grayish to reddish colors, gradually changing to horizon $\mathrm{C}$; some mottled marks can be seen, probably due to eluviation of Fe from upper layers. Biotite-rich facies of the granite alters to a reddish saprolite, occuring along with the white saprolite. Horizon C is similar to B but both the texture and structure of the granite is better preserved.

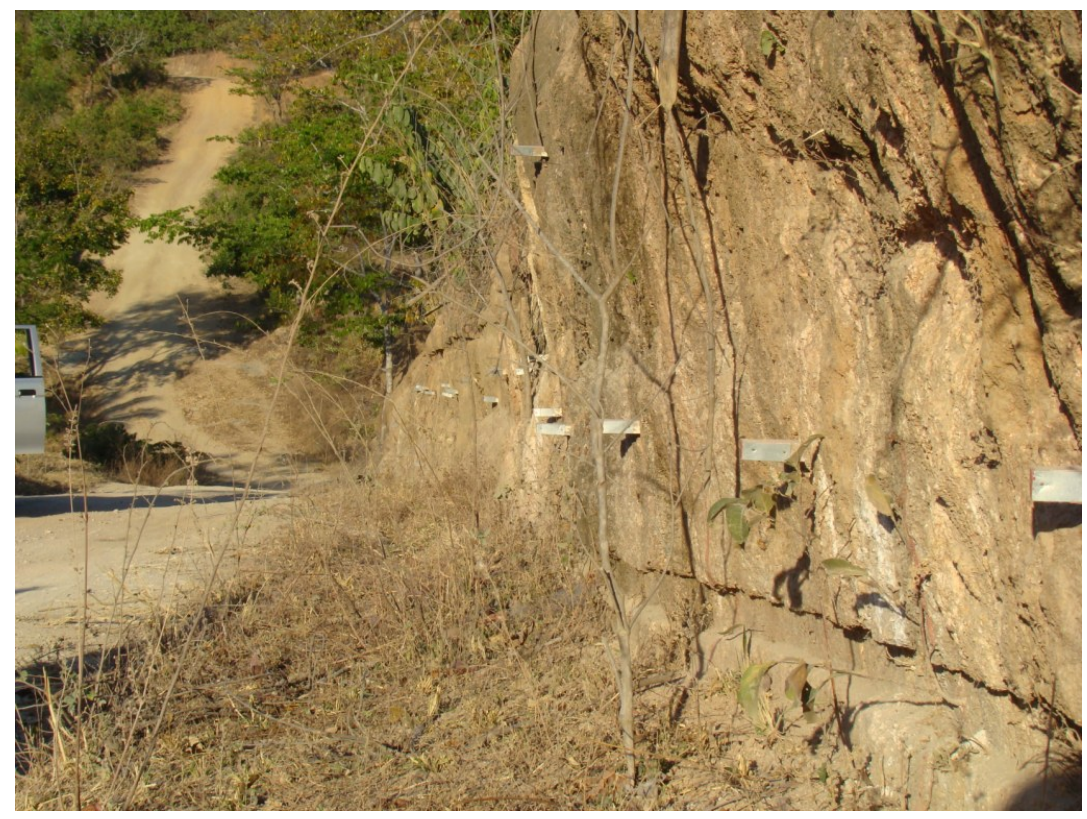

Figure 3: Saprolitic profile formed at the expense of the biotite granite.

The idendity of major minerals were doubled-checked with x-ray diffractometer (XRD). Figure 4 exhibits the patterns obtained for both the saprolite and clayish horizon (described in the next subsection). The analyses yielded sharp peaks of quartz and feldspars, with several minor peaks ascribed to the clay minerals and micas. Part of the REE budget in the saprolite is controlled by monazite-(Ce), xenotime-(Y) and zircon that remain in the altered rock as resistant minerals. It is believed that the remainder is made up by REE ions adsorbed on clay minerals and other newly-formed, supergene REE-minerals but this is subject to further analyses. Whole rock analyses of the saprolite can be seen in the Table A.1 - Appendix A: sample SAP. Sieving and panning the saprolite did not result in satisfactory recovery of heavy minerals. Among the few specimens that were recovered are monazite-(Ce), ilmenite, zircon and rutile, all of them in lower amounts when compared with the alluvial sediments.

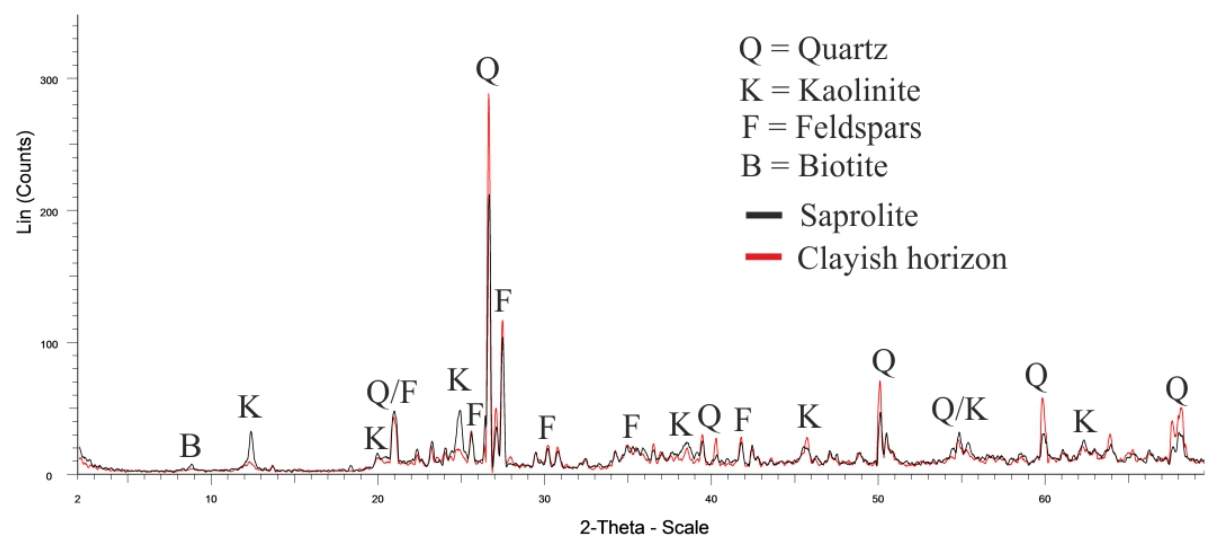

Figure 4: X-ray patterns of the saprolite and the clayish horizon. Quartz appears as a stronger peak than it actually is. 


\subsection{Clayish horizon}

Areas in between the granite hills act as sinks for the clay minerals leached and transported from uphill granitoids. Also, the slope of such areas is less steep so that the clay minerals that were formed in situ are not extensively leached away, remaining in place and forming a discrete horizon. The clayish horizon occurs in the bottom of horizon B, above the REE-rich alluvial sediments. The layer has a constant grayish to white colors, thickness of approximately 0.5 to $1.5 \mathrm{~m}$ and laterally continuous (Figure 5a). Total rock analyses of the clayish horizon (sample $\mathrm{CH}$ ) can be seen in the Table A.1 - Appendix A.

Major mineralogy was checked with XRD. The pattern is similar to the saprolite pattern, yielding quartz, feldspars and kaolinite (probably the hydrated form halloysite) as major minerals (Figure 4). Minor peaks are ascribed to muscovite and illite; biotite virtually is absent. Heavy minerals are virtually absent in the clayish horizon. The clays were leached away using water in $500 \mu \mathrm{m}$ sieves, retaining only quartz and muscovite.

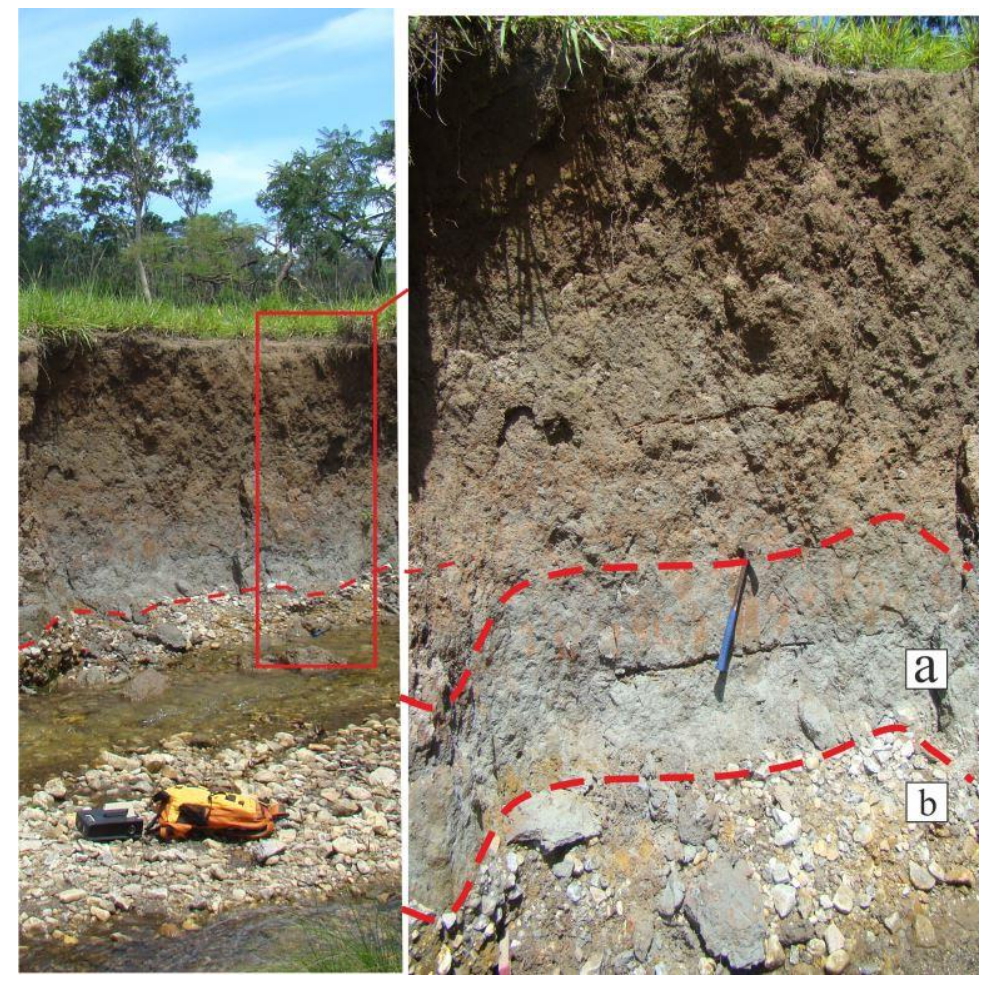

Figure 5: Profile at the margin of the Retiro Creek. (a) Soil cover and a gray clayish horizon overlapping the unconsolidated REE-bearing alluvial sediments. (b) Mode of occurrence of monazite-(Ce) and xenotime-(Y) among alluvial sediments. Monazite-(Ce) and xenotime-(Y) lie at the bottommost layer, along with other heavy minerals, quartz pebbles, sand and silt particles.

\subsection{Alluvial sediments}

The SDG is a higher relief domain when compared to the surrounding units. It is drained by several streams ranging from first order headwaters to small rivers mostly formed by fluvial downcutting. The running water weathered and leached the upper domains of the massif, depositing the more resistant/denser minerals in areas where the terrain becomes flatter, or where the slope decreases sufficiently. Alluvial sediments were collected in both high and low-slope terrains, but rare earth minerals were found only in the latter case. Detrital monazite- $(\mathrm{Ce})$ and xenotime- $(\mathrm{Y})$ occur locally laying on the inside margins of small meanders, behind physical barriers (logs, boulders) and trapped in potholes. In larger creeks they occur downstream along with poorly-sorted sediments derived from the weathered granite, transported in high-energy flows during rainy seasons. The latter situation is more significant in terms of volume and areal distribution. The 
heavy minerals are accumulated with coarse alluvial sediments along the channel of medium-sized streams such as the Retiro Creek. The sediments are loose, unconsolidated and poorly-selected, mostly composed of quartz (pebbles and cobbles), silt and clays (Figure 5b). During flood seasons, the layer is more active and mobile due to high-energy water flow, whereas during dry seasons the energy is not high enough to transport the constituents, which are left behind forming a pavement of poorly-sorted particles. Millimetric heavy minerals, sand, silt and clay-sized particles are incorporated in the alluvial sediments during flood seasons, as it is transported by the water and accommodated in the interstices of quartz pebbles and cobbles. Morphologically, the gravels form a homogeneous layer with no distinctive head and tail, extending from one margin to the other.

The REE contents of samples AS1 to AS5 reflect the original granite mineralogy, in that LREE-selective minerals predominate over HREE-selective ones (Table A.1 - Appendix 1). Assuming that nearly all LREE are partitioned in monazite-(Ce) it makes up to $0.87 \mathrm{wt} \%$ of the alluvial sediments. Likewise, considering that nearly all HREE are partitioned in xenotime-(Y) it represents up to $0.46 \mathrm{wt} \%$. Among the heavy minerals zircon may contain some REE replacing Zr but compared with REE-minerals the content is negligible. REEminerals such as apatite, allanite and bastnäsite do not withstand fluvial transportation and were not found among the alluvial sediments.

\subsubsection{Heavy minerals}

The saprolite, as well as the five samples of alluvial sediments were panned in order to concentrate its heavy minerals. The concentrate was submitted to XRD in order to identify the major constituents, with detection limits around $5 \%$. The analyses yielded monazite- $(\mathrm{Ce})$, ilmenite, zircon, garnet and xenotime-(Y) as major minerals (Figure 6). Combining observations with binocular microscope and the XRD analyses, monazite-(Ce), ilmenite and zircon make up to $80 \%$ of the total variability of the concentrate.

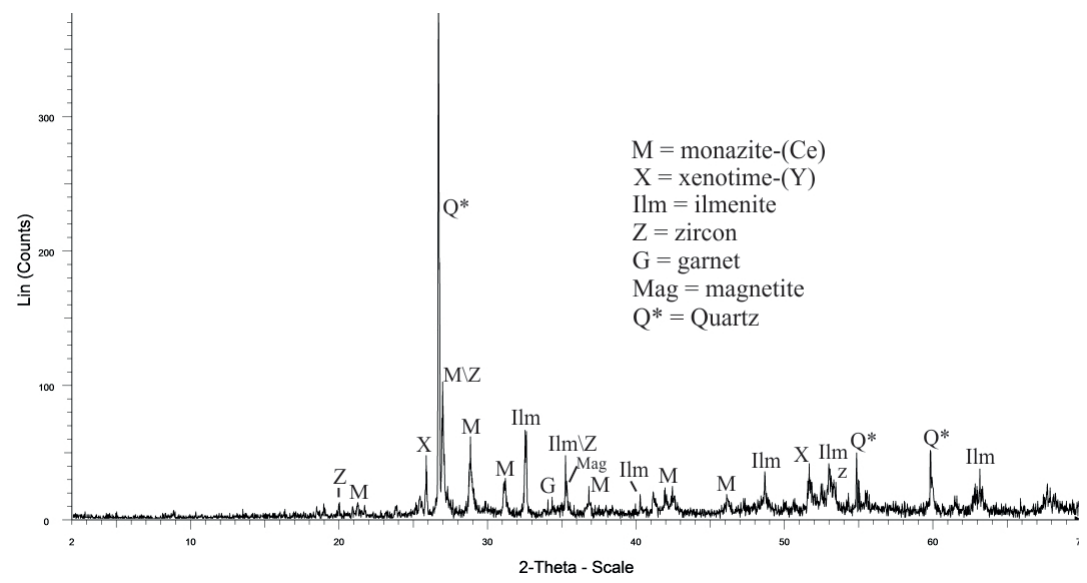

Figure 6: XRD spectra of the heavy minerals concentrate. ${ }^{*}$ Quartz is not a heavy mineral but some of it always remains among the heavy constituents after the panning. Quartz appears as a stronger peak than it actually is.

Minor constituents include rutile, fergusonite, titanite, tourmaline, staurolite, cassiterite, gahnite (Figure 7a-f). Grain size ranges from 0.1 to $2 \mathrm{~mm}$, anhedral to euhedral grains, fractures are common. Monazite-(Ce) and xenotime- $(\mathrm{Y})$ are described in more detail further because they are the main REE carriers. Detrital monazite-(Ce) occurs in sizes ranging from 0.3 up to $1.5 \mathrm{~mm}$, euhedral to anhedral grains, color varying from reddish brown to light yellow. Variation in color towards darker colors occur in the majority of the grains, preferentially taking place along fractures and more developed in grains more intensely metamictized. The luster is vitreous but some of it is lost due to abrasion during fluvial transportation. Xenotime- $(\mathrm{Y})$ is the second REE-bearing mineral in abundance. It occurs as subhedral to euhedral crystals, short tetragonal prisms with pyramidal terminations. Grain sizes vary from 0.4 to $1.2 \mathrm{~mm}$, average of $0.5 \mathrm{~mm}$. Since xenotime(Y) and zircon are isostructural, it is not always possible to distinguish between them with naked eyes, but 
the former tends to develop shorter prisms than the latter. Zircon's color also vary more, ranging from light yellow to colorless, while xenotime-(Y) was found with dark yellow to dark brown colors.
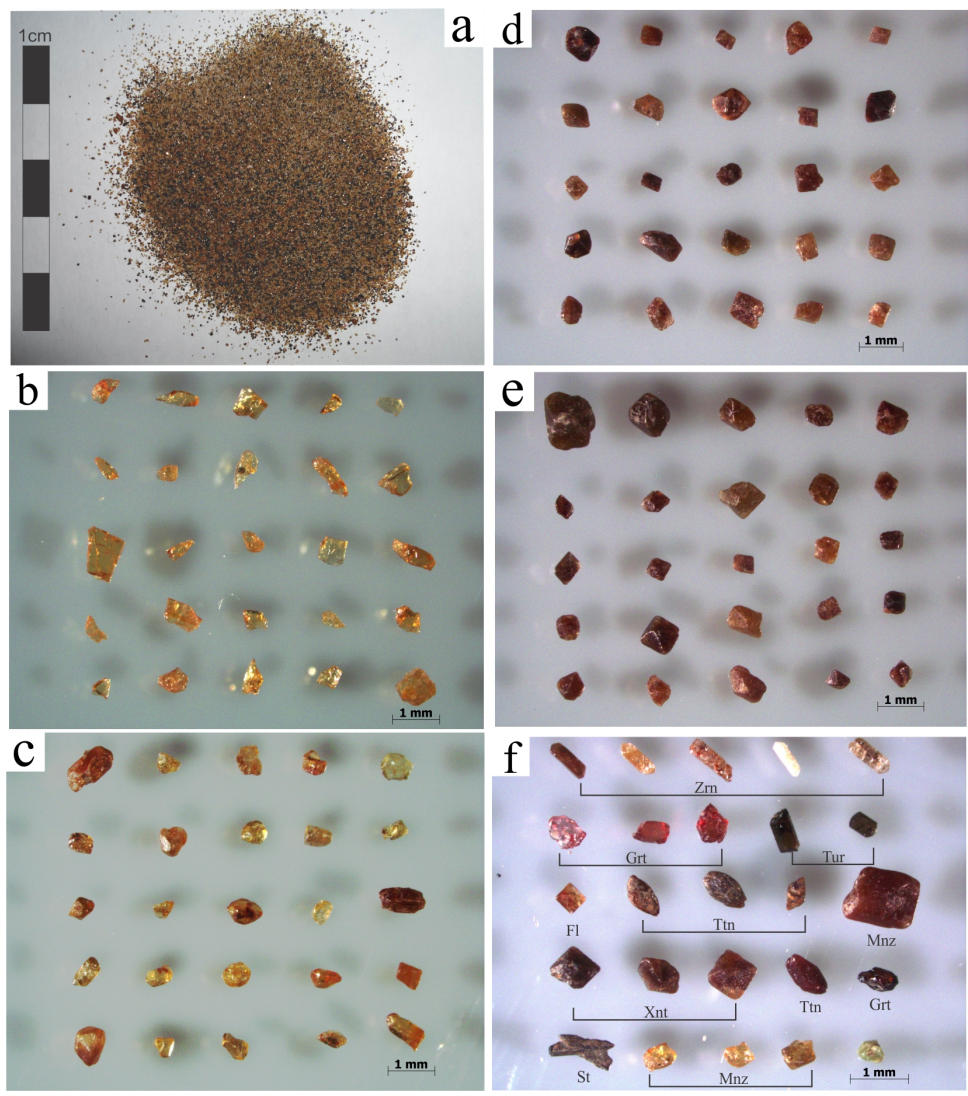

Figure 7: Images of the recovered heavy minerals under a binocular lens. (a) General aspect of the concentrate, composed mainly of monazite- $(\mathrm{Ce})$, zircon and magnetite. (b) Monazite-(Ce) sampled from the saprolite. (c) Detrital monazite-(Ce) sampled from stream sediments. (d) and (e) Detrital xenotime-(Y) recovered from the alluvial sediments in heavy mineral sands. (f) Other heavy minerals that occur with monazite $-(\mathrm{Ce})$ and xenotime- $(\mathrm{Y}) ; \mathrm{Znc}=$ zircon; Grt = garnet; Tur = tourmaline; Fl = fluorite; Ttn = titanite; $\mathrm{Mnz}=$ monazite; $\mathrm{Xnt}=$ xenotime; $\mathrm{St}=$ staurolite.

\subsection{Texture and composition of monazite-(Ce)}

Detrital monazite-(Ce) was studied in detail with EPMA (Figure 8a-c). The majority of the grains are subhedral and/or rounded and homogeneous, but some of them are compositionally zoned, with parallel brighter ribbon-like zones. Zoned crystals are preferentially euhedral, with cuspate edges. Back scattered images (BSE) reveal that some monazite- $(\mathrm{Ce})$ grains occur associated with xenotime-(Y), zircon and thorite. Xenotime- $(\mathrm{Y})$ may occur included in monazite- $(\mathrm{Ce})$ forming irregular amoeboid shapes.

Table 1 reports representative EPMA carried out in detrital and saprolitic monazite- $(\mathrm{Ce})$, on both pristine and altered grains. With no exception Ce is the dominant REE, followed by La, Nd, Pr and Sm. Total LREE are approximately the same in all the analysed grains, around $57 \mathrm{wt} \%$, but the La contents in saprolitic monazite-(Ce) are about 11wt\% higher than those from detrital specimens. Among the HREE, only Y, Gd and Dy yielded notable levels. The Th largely controls the actinide levels in monazite-(Ce), yielding notable grades up to $14.5 \mathrm{wt} \%$ in detrital grains. The phosphorus contents are approximately constant, average of $26 \mathrm{wt} \%$. Figure 9 exhibits the results of this study in comparison with average LREE and HREE contents from the studies of Demartin et al. (1991b); Teixeira (2002); Suzuki et al. (1994) and Van Emden et al. (1997). 
with no zonation. Occasionally, some grains exhibit irregular zonation with a patchy and mottled aspect, alternating between darker and brighter domains. According to Kositcin et al. (2003), this texture depicts variable degrees of substitution of HREE, $U$ and Th during magmatic evolution. Zonation within the grains is often closely associated with thorite inclusions, displayed as bright circular white dots. This texture is similar to that observed by Salgueiro et al. (2014) in detrital xenotime-(Y) from eastern Portugal. Putnis (2002) reports that when a mineral phase undergoes interaction with some reactive fluid, it may be either replaced by a modified phase of the original mineral or by a completely different phase.
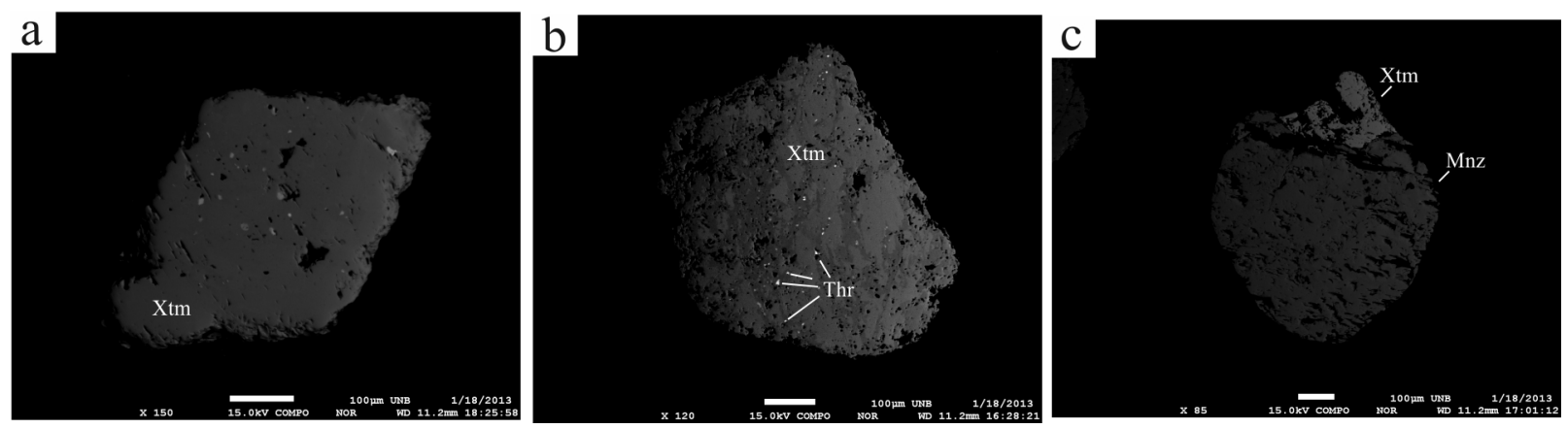

Figure 10: BSE images of detrital xenotime- $(\mathrm{Y})(\mathrm{Xtm})$. (a) Homogeneous euhedral specimen with some minor pitting of thorite(Thr) inclusions. (b) Detrital xenotime-(Y) exhibiting dissolution-reprecipitation pattern, some porosity and white dots of thorite inclusions. (c) Association between monazite-(Ce)(Mnz) and xenotime-(Y).

Table 2 reports representative EPMA on detrital xenotime-(Y). The results were compared with other studies such as Demartin et al. (1991a); Teixeira and Botelho (2006); Van Emden et al. (1997) and Foerster (1998) (Figure 11). The operating conditions of the EPMA 1 yielded Y contents approximately 10wt\% lower than the average found for xenotime-(Y) in other studies. It is believed that the operating conditions were underestimating $\mathrm{Y}$ so that we considered only the EPMA 2, more suitable to analyse xenotime- $(\mathrm{Y})$. The other HREE were detected in approximately the same levels under both operating conditions. The phosphorus ranges from 31 to $36 \mathrm{wt} \%$, which is in the same range of other studies. The LREE contents are typically low, frequently below the detection limits. Nd and Sm represent the highest values among the LREE. In contrast to monazite- $(\mathrm{Ce})$ the actinide levels in the xenotime- $(\mathrm{Y})$ are characterized by the predominance of $\mathrm{U}$ over Th.

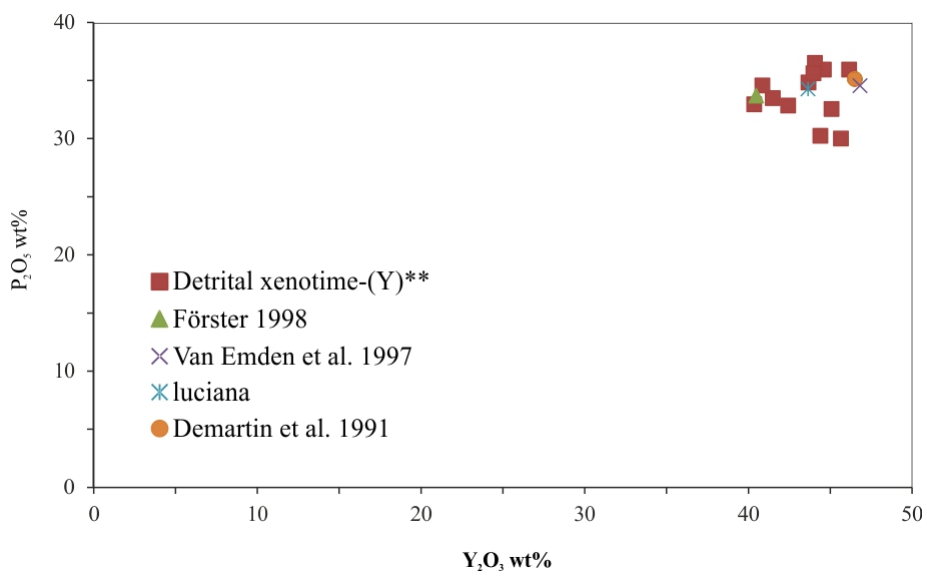

Figure 11: Contents of $\mathrm{Y}_{2} \mathrm{O}_{3}$ vs. $\mathrm{P}_{2} \mathrm{O}_{5}$ of detrital xenotime-(Y) compared with literature data. ${ }^{* *}$ EPMA 2. 
Table 2: Representative EPMA analyses of xenotime-(Y).

\begin{tabular}{lllllll}
\hline EPMA2 & $\begin{array}{l}\text { Range (wt\%) } \\
\text { Detrital(n=12) }\end{array}$ & Mean** & Std & & \multicolumn{2}{c}{ Atomic Proportion\# } \\
& & & & & Mean & Site \\
\hline Y2O3 & $40.36-46.16$ & 43.56 & 1.80 & $\mathrm{Y}$ & 0.802 & $\mathrm{~A}=0.992$ \\
$\mathrm{Gd} 2 \mathrm{O} 3$ & $0.31-1.75$ & 0.91 & 0.37 & $\mathrm{Gd}$ & 0.010 & \\
$\mathrm{~Tb} 2 \mathrm{O} 3$ & $<0.08^{*}-0.48$ & 0.25 & 0.12 & $\mathrm{~Tb}$ & 0.003 & \\
$\mathrm{Dy} 2 \mathrm{O} 3$ & $3.25-4.72$ & 4.28 & 0.41 & $\mathrm{Dy}$ & 0.048 & \\
$\mathrm{Ho} 2 \mathrm{O} 3$ & $0.79-1.50$ & 1.06 & 0.22 & $\mathrm{Ho}$ & 0.012 & \\
$\mathrm{Er} 2 \mathrm{O} 3$ & $2.33-4.79$ & 4.20 & 0.64 & $\mathrm{Er}$ & 0.046 & \\
$\mathrm{Yb} 2 \mathrm{O} 3$ & $2.63-6.22$ & 4.32 & 1.05 & $\mathrm{Yb}$ & 0.046 & \\
$\mathrm{Lu} 2 \mathrm{O} 3$ & $0.50-2.45$ & 1.47 & 0.65 & $\mathrm{Lu}$ & 0.015 & \\
$\mathrm{ThO} 2$ & $<0.06^{*}-1.08$ & 0.54 & 0.28 & $\mathrm{Th}$ & 0.004 & \\
$\mathrm{UO} 2$ & $0.08-3.19$ & 0.84 & 0.84 & $\mathrm{U}$ & 0.006 & $\mathrm{~B}=1.006$ \\
$\mathrm{SiO} 2$ & $0.06-0.91$ & 0.49 & 0.25 & $\mathrm{Si}$ & 0.017 & \\
$\mathrm{P} 2 \mathrm{O} 5$ & $30.01-36.51$ & 33.78 & 2.08 & $\mathrm{P}$ & 0.989 & \\
Total & $86.85-100.22$ & 95.71 & 4.04 & Total & 1.998 & \\
EPMA2 & Analyses carried out under operating conditions 2. \\
*Indicates values that are below the detection limits. \\
** Analyses below the detection limits were counted as having $0 \mathrm{wt} \%$ \\
for the determination of the average. \\
\#Calculated on the basis of 4 oxygen atoms. \\
Std = Standard deviation.
\end{tabular}

\section{Discussion}

The main discussions in this study are concerned with the supergene mobility and fractionation of REE, their secondary enrichment towards the alteration products of the granite and the alteration of detrital monazite-(Ce) and xenotime-(Y).

Both EPMA analyses revealed that detrital monazite-(Ce), saprolitic monazite- $(\mathrm{Ce})$ and detrital xenotime(Y) are more or less depleted in the REE when compared with other studies, with a few grains yielding good totals. The constant percolation of meteoric water and the presence of abundant organic matter in decomposition (leaves and roots) in the sample sites might contribute to low-totals since soil, roots and leaves release organic acids that can alter the minerals (Aide and Aide, 2012; Goyne et al., 2010; Pourret et al. 2007; Nagao et al., 1998, Tan, 1986). As stated by Goyne et al. (2010), the REE form stable complexes with organic acids, so that this may be a major pathway for REE mobility. Other common inorganic complexing agents that are likely to be present are carbonate, phosphate and fluorine anions that are released from plagioclase, apatite, and bastnäsite. The alteration of minerals is facilitated by the time span in which they were exposed to supergene conditions and physical abrasion during alluvial transport. Also, the decay chain of Th and U can damage the structure of the minerals, which would contribute to low totals. Aide and Aide (2012) stated that the stability constants of the aforementioned studies and the REE increase with increasing atomic number. Figure 12 shows that the hydrolysis with REE ions has greater stability towards the HREE. The same is observed for carbonic acids. Pearson's Rule (Pearson, 1963) is considered to be an important control on supergene REE stability, as observed by (Williams-Jones et al., 2012). The rule states that hard cations will bond preferentially with hard anions by means of ionic bonds, whereas soft, or polarizable, cations will bond with soft anions by means of covalent bonds. The definition of whether a cation is hard or soft is based on the ratio charge/ionic ratio. The ratio charge/radius ranges from $\mathrm{La}^{3+}=$ 2.56 to $\mathrm{Lu}^{3+}=3.00$, i.e., the larger the atomic number, the harder the cation. Therefore, HREE are more stable with a given hard anion than LREE (Williams-Jones et al., 2012).

It is believed that all the relevant elements present in monazite-(Ce) and xenotime-( $\mathrm{Y})$ were taken into account, so that the low-totals are mostly due to the variable alteration degree of the grains, or its high porosity. Van Emden et al. (1997) reported a similar situation in monazite and xenotime sampled from Australian placers. According to them the high porosity of the grains were responsible for the low-totals. 
In order to double-check the minerals Raman analyses were carried out in detrital specimens. Figure 13ab shows the spectra obtained for monazite- $(\mathrm{Ce})$ and xenotime- $(\mathrm{Y})$, which match with those found at the RRUFF database (Downs, 2006).
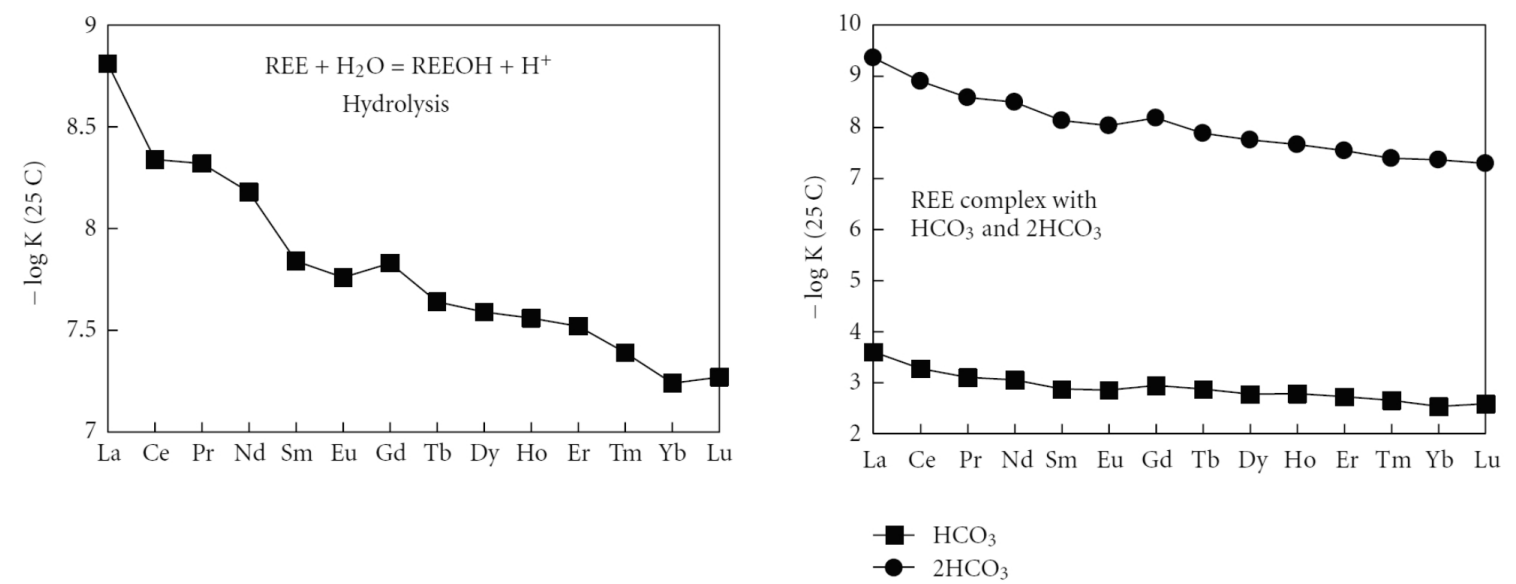

Figure 12: Stability constants for REE. Left chart: REE stability constants involving hydrolysis. After Klungness and Byrne (2000), In Aide and Aide (2012). Right chart: REE stability constants for $\mathrm{HCO}_{3}$ and $2 \mathrm{HCO}_{3}$. From Luo and Byrne (2004), In Aide and Aide (2012).

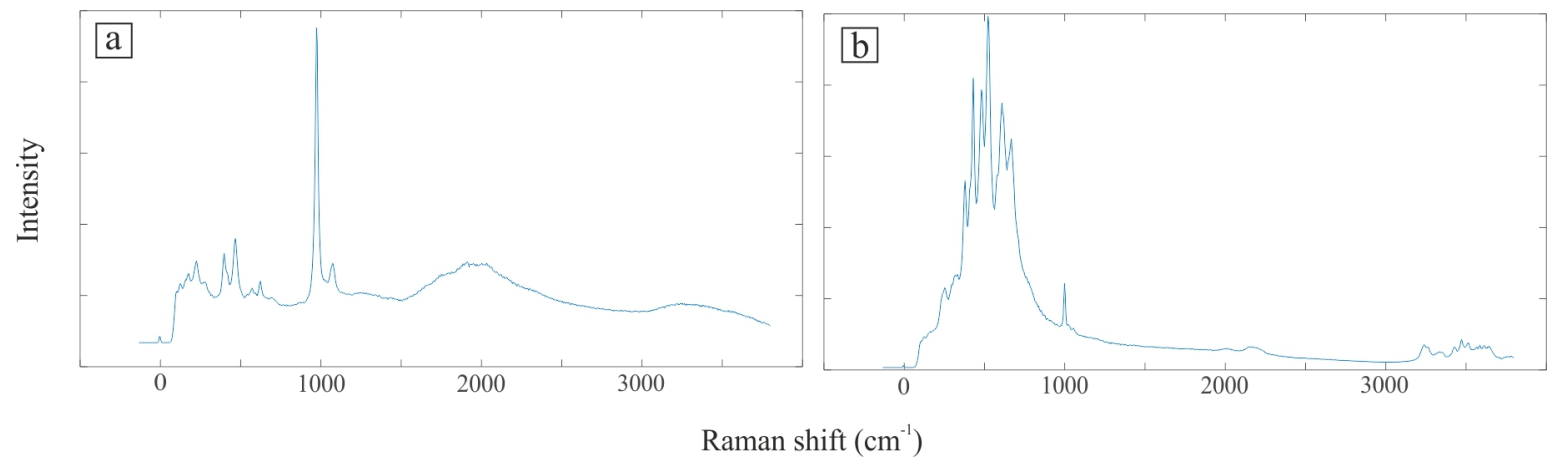

Figure 13: Raman spectra of detrital grains. (a) Spectrum of the detrital monazite-(Ce). (b) Spectrum of detrital xenotime- $(\mathrm{Y})$.

Total rock analyses in the sampled material give evidence of the supergene mobility and fractionation of the REE, in which successive enrichment is observed towards the products of alteration (Figure 14a-b). Despite the clayish horizon being less enriched than the saprolite, the former possess higher HREE contents due to the strong ability of these elements to be adsorbed by clay minerals formed at the expense of feldspars (Bau, 1991). The saprolite exhibits 3-fold enrichment in the LREE when compared with the fresh biotite granite, whereas in the clayish horizon the HREE are more enriched, also 3 times. As observed by Sanematsu et al. (2013), the positive Ce anomalies observed in the saprolite can be caused by immobilization of $\mathrm{Ce}^{4+}$ as $\mathrm{CeO}_{2}$. The REE grades of both saprolite and clayish horizon reported in this study allow comparison of the SDG with other residual REE deposits, mainly from China. In those, the average grades are 0.05-0.2wt\% (Kynicky et al., 2012).

The placers occurs locally, restricted to the course of a few creeks, consisting in a series of small prospects. These areas are also flat with low declivity, acting like sinks for the REE-rich alluvial sediments and the clays from uphill granitoids. The area of these occurrences is small when compared with beach and/or deltaic placers, in which large areas are covered with heavy minerals. On the other hand, the saprolite embraces a wider area because it is formed on the top of the whole massif, as well as on its immediate slopes. The area in which the saprolite occurs is much bigger than the area covered by the placers. 

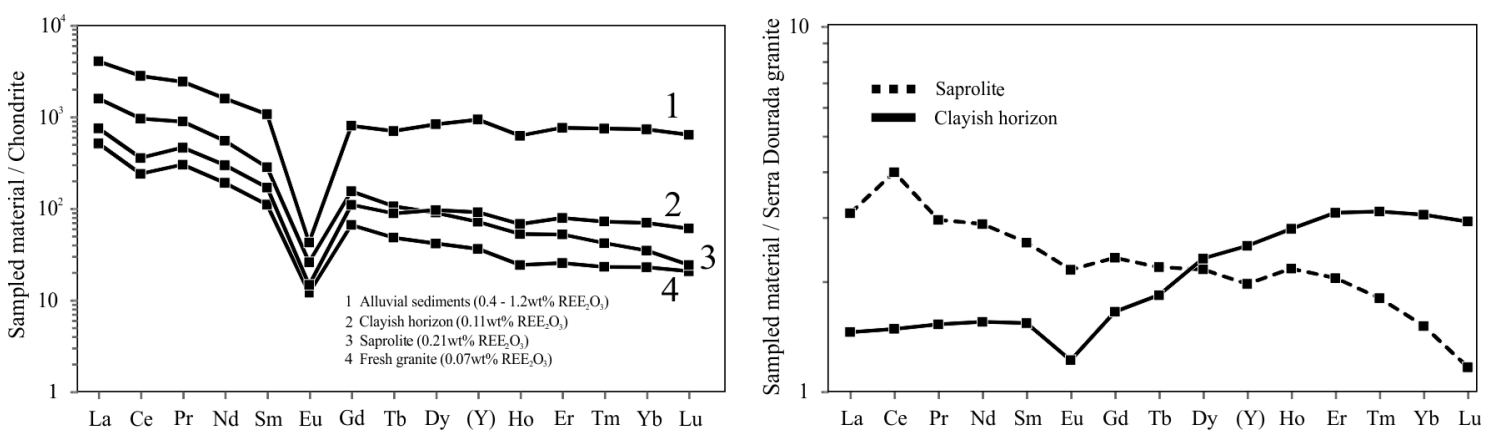

Figure 14: Chondrite-normalized REE patterns of the sampled material. Chondritic values of the left plot taken from Wakita et al. (1971). Right plot is a detail of lines 2 and 3, representing the REE patterns of the clayish horizon and saprolite normalized with the Serra Dourada Granite.

\section{Conclusions}

The reported results support the idea that REE are mobile under supergene conditions and during granite weathering. Considering the analyses from fresh rock to the ultimate products of weathering, the REE mobility is evident, tending to be higher and more fractionated towards the products of alteration (saprolite, alluvial sediments and the clayish horizon). REE enrichment in the fresh granite was favoured by its primary REE mineralogy, which includes both resistant and soluble REE minerals. The resistant minerals were accumulated in the alluvial sediments, whereas the soluble REE-minerals were broken down eventually releasing REE into the sedimentary system. It is possible that the enrichment in the clayish horizon is related with these free REE ions that adsorb on clay minerals but further investigation would be helpful in determining whether or not the adsorption occurs. Secondary, newly-formed REE minerals might also contribute to the overall REE budget of the clayish horizon. The low-totals of detrital monazite-(Ce) and xenotime- $(\mathrm{Y})$ are related with supergene weathering and alteration potentially by both organic and inorganic acids. The $\mathrm{REE}_{2} \mathrm{O}_{3}$ grades reported are approximately the same as for the residual REE deposits from China. In terms of distribution it was noted that the placers and the clayish horizon occur punctually and restricted to small flat areas within the granite, whereas the saprolite is developed all over the massif, reaching the top of hills and its immediate slopes.

\section{Acknowledgements}

The corresponding author is grateful to the Coordination for the Improvement of Higher Education Personnel (CAPES), an agency under the Ministry of Education of Brazil for having being granted with the scholarship BEX 11998/13-0. The authors are grateful to the Brazilian National Council for Scientific and Technological Development $(\mathrm{CNPq})$ for the financial support by means of the projects 550266/2011-9 and 305833/2010-3. The authors are also grateful to the reviewers for greatly improving the original manuscript and to the Raman, XRD and EPMA analysts. 


\section{A Appendix A1}

\begin{tabular}{|c|c|c|c|c|c|c|c|c|c|c|}
\hline Sample & FG1 & FG2 & FG3 & SAP & AS1 & AS2 & AS3 & $\mathrm{AS} 4$ & AS5 & $\mathrm{CH}$ \\
\hline \multicolumn{11}{|l|}{ Oxide (wt\%) } \\
\hline $\mathrm{SiO} 2$ & 78.29 & 74.57 & 76.69 & 53.63 & 84.50 & 72.44 & 85.38 & 83.33 & 76.82 & 63.78 \\
\hline $\mathrm{TiO} 2$ & 0.14 & 0.29 & 0.09 & 0.45 & 0.31 & 1.16 & 1.21 & 0.85 & 0.50 & 0.37 \\
\hline $\mathrm{Al} 2 \mathrm{O} 3$ & 11.22 & 12.11 & 12.49 & 26.92 & 7.04 & 9.46 & 3.65 & 6.16 & 9.91 & 20.58 \\
\hline $\mathrm{Fe} 2 \mathrm{O} 3$ & 1.15 & 2.36 & 1.32 & 3.62 & 1.25 & 2.15 & 1.92 & 1.48 & 1.20 & 1.31 \\
\hline $\mathrm{MnO}$ & 0.02 & 0.02 & 0.05 & 0.02 & 0.01 & 0.05 & 0.10 & 0.11 & 0.04 & 0.01 \\
\hline $\mathrm{MgO}$ & 1.03 & 0.21 & 0.07 & 0.17 & 0.08 & 0.08 & 0.02 & 0.06 & 0.14 & 0.26 \\
\hline $\mathrm{CaO}$ & 0.57 & 0.69 & 1.07 & 0.02 & 0.04 & 0.13 & 0.05 & 0.27 & 0.32 & 0.08 \\
\hline $\mathrm{Na} 2 \mathrm{O}$ & 3.27 & 2.17 & 3.64 & 0.18 & 0.25 & 0.32 & 0.12 & 0.62 & 0.92 & 0.52 \\
\hline $\mathrm{K} 2 \mathrm{O}$ & 3.29 & 5.97 & 3.72 & 4.87 & 2.80 & 4.62 & 1.68 & 3.06 & 4.36 & 5.69 \\
\hline $\mathrm{P} 2 \mathrm{O} 5$ & 0.02 & 0.05 & 0.02 & 0.07 & 0.22 & 0.50 & 0.48 & 0.65 & 0.23 & 0.02 \\
\hline LOI & 0.8 & 1.3 & 0.6 & 9.6 & 2.5 & 5.3 & 2.4 & 1.5 & 4.7 & 7.1 \\
\hline Total & 99.80 & 99.74 & 99.76 & 99.55 & 99.00 & 96.21 & 97.01 & 98.09 & 99.14 & 99.72 \\
\hline \multicolumn{11}{|l|}{$(p p m)$} \\
\hline $\mathrm{Rb}$ & 190.7 & 238.1 & 143.8 & 240.1 & 137.2 & 176.4 & 64.1 & 136.0 & 213.6 & 305.9 \\
\hline Cs & 1.2 & 1.2 & 0.6 & 2.1 & 1.2 & 0.6 & 0.5 & 0.7 & 1.7 & 2.9 \\
\hline $\mathrm{Ba}$ & 100 & 418 & 815 & 408 & 111 & 523 & 64 & 151 & 269 & 284 \\
\hline $\mathrm{Sr}$ & 21.5 & 79.2 & 325.3 & 31.6 & 10.7 & 43.6 & 7.4 & 28.2 & 39.2 & 26.5 \\
\hline $\mathrm{Ga}$ & 14.8 & 19.6 & 30.7 & 40.6 & 12.0 & 18.2 & 9.6 & 9.5 & 15.3 & 36.0 \\
\hline $\mathrm{Ta}$ & 0.9 & 0.8 & 5.9 & 1.7 & 7.5 & 15.0 & 557.1 & 69.4 & 8.9 & 4.3 \\
\hline $\mathrm{Nb}$ & 9.3 & 19.3 & 68.0 & 33.9 & 95.7 & 233.9 & 4832.5 & 213.9 & 57.5 & 64.8 \\
\hline $\mathrm{Th}$ & 51.1 & 72.0 & 33.8 & 191.2 & 267.3 & 757.3 & 576.7 & 1147.1 & 433.8 & 70.2 \\
\hline $\mathrm{U}$ & 10.0 & 6.2 & 6.1 & 16.6 & 45.2 & 94.2 & 237.1 & 136.0 & 56.9 & 8.8 \\
\hline $\mathrm{Pb}$ & 3.8 & 6.3 & 8.0 & 47.3 & 16.9 & 17.3 & 38.5 & 16.4 & 8.6 & 21.3 \\
\hline $\mathrm{Sn}$ & 5 & $<1$ & $<1$ & 2 & 66 & 5 & 797 & 230 & 59 & 11 \\
\hline $\mathrm{Co}$ & 1.5 & 3.2 & 2.2 & 3.1 & 1.0 & 1.7 & 1.8 & 1.1 & 1.2 & 1.7 \\
\hline $\mathrm{Zr}$ & 279.8 & 315.7 & 214.7 & 533.9 & 3050.2 & 18751.3 & 5744.8 & 1721.4 & 2100.6 & 690.0 \\
\hline Hf & 10.7 & 10.9 & 9.3 & 17.0 & 115.1 & 581.3 & 206.6 & 58.6 & 71.3 & 24.7 \\
\hline $\mathrm{Y}$ & 41.6 & 48.0 & 96.9 & 122.9 & 832.7 & 1185.2 & 2944.4 & 2348.2 & 714.4 & 156.1 \\
\hline $\mathrm{La}$ & 193.4 & 217.6 & 118.3 & 544.2 & 665.7 & 1837.3 & 1401.0 & 2193.7 & 824.2 & 257.5 \\
\hline $\mathrm{Ce}$ & 121.4 & 322.8 & 214.7 & 877.6 & 1243.8 & 3476.4 & 2508.7 & 4214.7 & 1419.7 & 327.1 \\
\hline $\operatorname{Pr}$ & 44.81 & 40.72 & 24.72 & 108.76 & 147.68 & 379.20 & 328.63 & 456.83 & 168.41 & 56.34 \\
\hline $\mathrm{Nd}$ & 147.6 & 135.0 & 86.5 & 354.6 & 508.6 & 1279.1 & 1217.7 & 1547.2 & 562.2 & 191.6 \\
\hline $\mathrm{Sm}$ & 24.92 & 22.98 & 17.02 & 55.51 & 103.32 & 237.24 & 303.00 & 297.99 & 107.57 & 33.43 \\
\hline $\mathrm{Eu}$ & 0.98 & 0.96 & 0.71 & 1.91 & 1.82 & 4.85 & 3.56 & 3.72 & 1.74 & 1.08 \\
\hline $\mathrm{Gd}$ & 18.58 & 17.62 & 15.84 & 40.44 & 100.53 & 210.35 & 356.39 & 286.34 & 98.20 & 28.76 \\
\hline $\mathrm{Tb}$ & 2.33 & 2.11 & 2.40 & 5.01 & 15.27 & 29.66 & 61.75 & 44.77 & 14.70 & 4.20 \\
\hline Dy & 12.31 & 10.49 & 14.97 & 27.28 & 118.13 & 207.42 & 489.84 & 337.42 & 107.59 & 29.18 \\
\hline Ho & 1.67 & 1.50 & 2.55 & 4.15 & 23.38 & 36.76 & 96.67 & 67.77 & 20.56 & 5.33 \\
\hline Er & 4.27 & 3.58 & 7.57 & 10.54 & 77.24 & 109.88 & 296.07 & 219.08 & 65.04 & 15.91 \\
\hline $\mathrm{Tm}$ & 0.61 & 0.41 & 1.22 & 1.35 & 12.65 & 17.00 & 45.27 & 35.12 & 10.33 & 2.33 \\
\hline $\mathrm{Yb}$ & 4.17 & 2.64 & 8.42 & 7.70 & 89.20 & 116.88 & 295.27 & 241.03 & 70.54 & 15.52 \\
\hline $\mathrm{Lu}$ & 0.56 & 0.32 & 1.25 & 0.83 & 12.52 & 16.00 & 39.17 & 32.42 & 9.58 & 2.08 \\
\hline LREE & 533.11 & 740.06 & 461.95 & 1942.58 & 2670.92 & 7214.09 & 5762.59 & 8714.14 & 3083.82 & 867.05 \\
\hline HREE+Y & 86.1 & 86.7 & 151.1 & 220.2 & 1281.6 & 1929.2 & 4624.8 & 3612.2 & 1110.9 & 259.4 \\
\hline $\mathrm{REE}+\mathrm{Y}$ & 619.21 & 826.73 & 613.07 & 2162.78 & 3952.54 & 9143.24 & 10387.42 & 12326.29 & 4194.76 & 1126.46 \\
\hline LREE/HREE & 6.19 & 8.54 & 3.06 & 8.82 & 2.08 & 3.74 & 1.25 & 2.41 & 2.78 & 3.34 \\
\hline $\mathrm{Ce} / \mathrm{Ce}^{*}$ & 0.29 & 0.76 & 0.88 & 0.80 & 0.88 & 0.93 & 0.82 & 0.94 & 0.85 & 0.61 \\
\hline $\mathrm{Eu} / \mathrm{Eu}^{*}$ & 0.14 & 0.15 & 0.13 & 0.12 & 0.06 & 0.07 & 0.03 & 0.04 & 0.05 & 0.11 \\
\hline$(\mathrm{La} / \mathrm{Yb}) \mathrm{N}$ & 30.01 & 53.33 & 9.09 & 45.73 & 4.83 & 10.17 & 3.07 & 5.89 & 7.56 & 10.74 \\
\hline$(\mathrm{Gd} / \mathrm{Yb}) \mathrm{N}$ & 3.77 & 5.65 & 1.59 & 4.44 & 0.95 & 1.52 & 1.02 & 1.01 & 1.18 & 1.57 \\
\hline
\end{tabular}

$\mathrm{Ce} / \mathrm{Ce}^{*}=\mathrm{CeN} /(\mathrm{LaNxPrN}) 1 / 2$

$\mathrm{Eu} / \mathrm{Eu}^{*}=\mathrm{EuN} /(\mathrm{SmNxGdN}) 1 / 2$

Chondritic values taken from Wakita et at., (1971) 


\section{References}

Aide, M. T., Aide, C., 2012. Rare earth elements: their importance in understanding soil genesis. ISRN Soil Science 2012.

Aubert, D., Stille, P., Probst, A., 2001. Ree fractionation during granite weathering and removal by waters and suspended loads: Sr and nd isotopic evidence. Geochimica et Cosmochimica Acta 65 (3), 387-406.

Bao, Z., Zhao, Z., 2008. Geochemistry of mineralization with exchangeable rey in the weathering crusts of granitic rocks in south china. Ore Geology Reviews 33 (3), 519-535.

Bau, M., 1991. Rare-earth element mobility during hydrothermal and metamorphic fluid-rock interaction and the significance of the oxidation state of europium. Chemical Geology 93 (3), 219-230.

Bilal, E., Moutte, J., Botelho, N., Marini, O., Andrade, G., 1997. Geochemistry of two proterozoic a-type granites of goiás state, brazil: possible links with rapakivi series. Annals of the Brazilian Academy of Sciences 69, 349-365.

Boulangé, B., Colin, F., 1994. Rare earth element mobility during conversion of nepheline syenite into lateritic bauxite at passa quatro, minais gerais, brazil. Applied Geochemistry 9 (6), 701-711.

Chengyu, W., Dianhao, H., Zhongxun, G., 1990. REE Geochemistry in the Weathered Crust of Granites, Longnan Area, Jiangxi Province. Acta Geologica Sinica - English Edition 3 (2), 193-209.

Condie, K. C., Dengate, J., Cullers, R. L., 1995. Behavior of rare earth elements in a paleoweathering profile on granodiorite in the front range, colorado, USA. Geochimica et Cosmochimica Acta 59 (2), 279-294.

Coppin, F., Berger, G., Bauer, A., Castet, S., Loubet, M., 2002. Sorption of lanthanides on smectite and kaolinite. Chemical Geology 182 (1), 57-68.

Demartin, F., Pilati, T., Diella, V., Donzelli, S., Gentile, P., Gramaccioli, C. M., 1991a. The chemical composition of xenotime from fissures and pegmatites in the alps. Canadian Mineralogist 29, 69-75.

Demartin, F., Pilati, T., Diella, V., Donzelli, S., Gramaccioli, C. M., 1991b. Alpine monazite: further data. Can. Mineral 29, 61-67.

Downs, R., 2006. The rruff project: an integrated study of the chemistry, crystallography, raman and infrared spectroscopy of minerals. In: Program and Abstracts of the 19th General Meeting of the International Mineralogical Association in Kobe, Japan. Vol. 3.

Duddy, L. R., 1980. Redistribution and fractionation of rare-earth and other elements in a weathering profile. Chemical Geology 30 (4), 363-381.

Foerster, H.-J., 1998. The chemical composition of ree-y-th-u rich accessory minerals in peraluminous granites of the erzgebirge-fichtelgebirge region, germany. part ii: Xenotime. American Mineralogist 83 (11-12), 1302-1315.

Goyne, K. W., Brantley, S. L., Chorover, J., 2010. Rare earth element release from phosphate minerals in the presence of organic acids. Chemical Geology 278 (1), 1-14.

Klungness, G. D., Byrne, R. H., 2000. Comparative hydrolysis behavior of the rare earths and yttrium: the influence of temperature and ionic strength. Polyhedron 19 (1), 99-107.

Kositcin, N., McNaughton, N. J., Griffin, B. J., Fletcher, I. R., Groves, D. I., Rasmussen, B., 2003. Textural and geochemical discrimination between xenotime of different origin in the archaean witwatersrand basin, south africa. Geochimica et Cosmochimica Acta 67 (4), 709-731.

Kynicky, J., Smith, M. P., Xu, C., 2012. Diversity of rare earth deposits: the key example of china. Elements 8 (5), 361-367.

Long, K. R., Van Gosen, B. S., Foley, N. K., Cordier, D., 2012. The principal rare earth elements deposits of the United States: a summary of domestic deposits and a global perspective. Springer.

Luo, Y.-R., Byrne, R. H., 2004. Carbonate complexation of yttrium and the rare earth elements in natural waters. Geochimica et Cosmochimica Acta 68 (4), 691-699. 
Macambira, M. J. B., 1983. Ambiente geológico e mineralizações associadas ao granito serra dourada (extremidade meridional)-goiás. Ph.D. thesis, University of Pará.

Marini, O., Botelho, N., 1986. A província de granitos estaníferos de goiás. Brazilian Journal of Geology 16 (1), $119-131$.

Mentani, T., Ohmura, T., Watanabe, Y., Urabe, T., 2010. So-called ion-adsorption type ree deposits found in weathered crust of ilmenite-series granite in northern vietnam. In: 2010 GSA Denver Annual Meeting.

Murakami, H., Ishihara, S., 2008. Ree mineralization of weathered crust and clay sediment on granitic rocks in the sanyo belt, sw japan and the southern jiangxi province, china. Resource Geology 58 (4).

Nagao, S., Rao, R., Killey, R., Young, J., 1998. Migration behavior of eu (iii) in sandy soil in the presence of dissolved organic materials. Radiochimca Acta 82 (Supplement), 205-212.

Nesbitt, H. W., 1979. Mobility and fractionation of rare earth elements during weathering of a granodiorite. Nature 279, 206-210.

Pearson, R. G., 1963. Hard and soft acids and bases. Journal of the American Chemical Society 85 (22), 3533-3539.

Petersen Jr, K. J., Schultz-Güttler, R. A., da Silveira Bello, R. M., 2008. Alexandrita do Pela Ema, Minaçú/go: inclusões fluidas e condições genéticas. Brazilian Journal of Geology 32 (3), 307-316.

Pimentel, M. M., Heaman, L., Fuck, R. A., Marini, O. J., 1991. U-pb zircon geochronology of precambrian tin-bearing continental-type acid magmatism in central brazil. Precambrian Research 52 (3), 321-335.

Pourret, O., Davranche, M., Gruau, G., Dia, A., 2007. Competition between humic acid and carbonates for rare earth elements complexation. Journal of colloid and interface science 305 (1), 25-31.

Putnis, A., 2002. Mineral replacement reactions: from macroscopic observations to microscopic mechanisms. Mineralogical Magazine 66 (5), 689-708.

Rapp, R. P., Watson, E. B., 1986. Monazite solubility and dissolution kinetics: implications for the thorium and light rare earth chemistry of felsic magmas. Contributions to Mineralogy and Petrology 94 (3), 304-316.

Ruan, C., Guocai, Z., 1998. Rare earth partitioning on granitoid weathering in southern china. Trans. Nonferrous Met. Soc. China 8 (4), 693-699.

Salgueiro, R., Rosa, D., Inverno, C., de Oliveira, D., Solá, A. R., Guimarães, F., 2014. Alluvial xenotime and heavy minerals assemblage from the northern edge of nisa-albuquerque batholith, eastern portugal: Provenance and geochemical implications. Journal of Geochemical Exploration 146, 40-57.

Sanematsu, K., Kon, Y., Imai, A., Watanabe, K., Watanabe, Y., 2013. Geochemical and mineralogical characteristics of ion-adsorption type ree mineralization in Phuket, Thailand. Mineralium Deposita 48 (4), 437-451.

Sanematsu, K., Murakami, H., Watanabe, Y., Duangsurigna, S., Siphandone, V., 2009. Enrichment of rare earth elements (ree) in granitic rocks and their weathered crusts in central and southern laos. Bulletin of the Geological Survey of Japan 60 (11-12), 527-558.

Suzuki, K., Adachi, M., Kajizuka, I., 1994. Electron microprobe observations of pb diffusion in metamorphosed detrital monazites. Earth and Planetary Science Letters 128 (3), 391-405.

Tan, K. H., 1986. Degradation of soil minerals by organic acids. Interactions of soil minerals with natural organics and microbes (interactionsofs), 1-27.

Teixeira, L. M., 2002. Caracterização de minerais portadores de terras raras e sua aplicação 'a petrologia e geocronologia de granitos das subprovíncias tocantins e paranã - goiás. Ph.D. thesis, University of Brasília.

Teixeira, L. M., Botelho, N. F., 2006. Comportamento geoquímico de etr durante evolução magmática e alteração hidrotermal de granitos: exemplos da província estanífera de goiás. Brazilian Journal of Geology 36 (4), $679-691$.

Van Emden, B., Thornber, M. R., Graham, J., Lincoln, F. J., 1997. The incorporation of actinides in monazite and xenotime from placer deposits in western australia. Canadian Mineralogist 35, 95-104. 
Wakita, H., Rey, P., Schmitt, R., 1971. Abundances of the 14 rare-earth elements and 12 other trace elements in apollo 12 samples: five igneous and one breccia rocks and four soils. In: Lunar and Planetary Science Conference Proceedings. Vol. 2. p. 1319.

Williams-Jones, A. E., Migdisov, A. A., Samson, I. M., 2012. Hydrothermal mobilisation of the rare earth elements-a tale of ceria and yttria. Elements 8 (5), 355-360.

Wu, C., Yuan, Z., Bai, G., 1996. Rare earth deposits in china. In: Jones, A. P., Wall, F., Williams, C. T. (Eds.), Rare Earth Minerals: chemistry, origin and ore deposits. Vol. 7. Mineralogical Society Series, pp. 281-310. 